\title{
TOPIK PILIHAN MAHASISWA TIONGKOK DALAM PEMBELAJARAN BIPA PROGRAM TRANSFER KREDIT DI UNY
}

\author{
Ari Kusmiatun \\ FBS Universitas Negeri Yogyakarta \\ email: akusmiatun@gmail.com
}

\begin{abstract}
Abstrak
Penelitian ini bertujuan mendeskripsikan topik pilihan mahasiswa Tiongkok dalam pembelajaran BIPA program transfer kredit di Universitas Negeri Yogyakarta. Subjek penelitian adalah mahasiswa Tiongkok peserta program transfer kredit di UNY. Pengumpulan data dengan angket, wawancara, dan dokumentasi. Hasil penelitian menunjukkan bahwa secara umum mahasiswa Tiongkok menyukai topik belajar wisata/rekreasi. Pada keterampilan menulis mahasiswa dominan memilih topik wisata/rekreasi. Pada keterampilan membaca mahasiswa memilih topik kuliner, wisata, dan hiburan. Pada keterampilan berbicara-menyimak topik yang diminati adalah dunia hiburan. Alasan pemilihan topik di antaranya: geografi dan alam Indonesia yang indah, keingintahuan tentang tempat wisata Indonesia, variasi makanan Indonesia, perbedaan budaya Indonesia dan Tiongkok, dan perkembangan ekonomi dua negara. Bagi mahasiswa, belajar dengan topik yang disukai dapat mempermudah mempelajari bahasa Indonesia.
\end{abstract}

Kata kunci: topik belajar, pembelajaran BIPA, keterampilan berbahasa

\section{THE TOPICS CHINESE STUDENTS SELECT IN THE LEARNING OF ILFS FOR THE CREDIT TRANSFER PROGRAM}

\begin{abstract}
This study aims to describe the topics Chinese students select in the learning of Indonesian language for foreign speakers (ILFS) for the credit transfer program at Yogyakarta State University (YSU). The research subjects were Chinese students joining the credit transfer program at YSU. The data were collected through questionnaires, interviews, and documentation. The findings show that in general Chinese students like the topic of tourism/recreation. For the writing skill, most of them like the topic of tourism/ recreation. For the reading skill, they like the topics of foods, tourism, and entertainment. For the listening and speaking skills, they like the topic of entertainment. The reasons for the topic selection include, among others, beautiful Indonesian geography and nature, curiosity about tourist attractions in Indonesia, varieties of Indonesian foods, differences between Indonesian and Chinese cultures, and the two countries' economic development. For them, the topics they like facilitate their Indonesian language learning.
\end{abstract}

Keywords: learning topics, learning of ILFS, language skills

\section{PENDAHULUAN}

Pembelajaran bahasa Indonesia berkembang seiring kebutuhan dan kemajuan zaman. Salah satunya adalah keberadaan pembelajaran Bahasa Indonesia bagi Penutur Asing (BIPA) yang main luas dan diakui keberadaannya. Pembelajaran BIPA berkembang, baik di dalam negeri maupun di luar negeri. Dalam perkembangannya, terdapat beberapa jenis pem- 
belajaran BIPA. Salah satunya adalah pembelajaran BIPA yang diperuntukkan bagi mahasiswa asing yang mengambil bahasa Indonesia sebagai pilihan dalam studi lanjutnya.

Di beberapa universitas di luar negeri, Bahasa Indonesia menjadi pilihan untuk dipelajari. Sebagian universitas menempatkannya sebagai pilihan utama dan sebagian lain menjadi sebuah bagian yang mendukung studi pilihannya. Namun demikian, semua menjadi jalan bagi bahasa Indonesia untuk berkembang. Adanya program pembelajaran BIPA di luar ini memberi dampak pula perkembangan BIPA di dalam negeri.

Salah satu pengaruh yang dirasakan secara langsung adalah adanya peluang pengembangan BIPA di berbagai instansi penyelenggara BIPA di dalam negeri untuk menjadi mitra bagi penyelenggara BIPA di luar negeri. Salah satu hal penting dalam belajar bahasa asing adalah mempraktikkannya dalam komunitas atau masyarakat pemilik bahasa tersebut. Artinya, pembelajaran BIPA akan baik dilakukan secara embeded atau nyemplung dalam lingkungan penutur aslinya. Brown (2007) mengungkapkan bahwa pembelajaran bahasa kedua (asing) yang paling baik adalah berada dalam konteksnya dan komunikasi yang bermakna, yaitu praktik langsung. Hal ini yang membawa peluang adanya program transfer kredit di universitas penyelenggara BIPA di Indonesia. Program ini akan bermanfaat bagi kedua universitas yang bersangkutan, salah satunya adalah UNY.

Sudah 5 tahun UNY menjalin kerjasama dengan Guangdhong University for Foreign Studies (GDUFS) sebagai mitra program transfer kredit bagi mahasiswa GDUFS yang mengambil jurusan bahasa Indonesia. Hal serupa juga terjadi selama 3 tahun ini dengan Yunan Minzu University. Setiap tahunnya ada sekitar 40 mahasiswa asing dari Tiongkok yang belajar di UNY dalam program transfer kredit.
Program ini menyajikan berbagai mata kuliah yang di program sesuai kebutuhan mahasiswa. Secara umum, pembelajaran BIPA mencakup empat keterampilan berbahasa dan pengetahuan kebahasaindonesiaan. Pembelajaran didesain dengan acuan topik dalam tiap materinya. Belajar bahasa Indonesia dalam program BIPA berbeda dengan belajar bahasa Indonesia pada umumnya. Pengajar harus mampu membawa materi bahasa secara mudah, menyenangkan, dan menarik bagi pembelajar BIPA. Topik yang menarik menjadi salah satu daya pikatnya.

Bagaimanapun pembelajaran akan berhasil jika materinya disukai oleh mahasiswa dan nyaman diterima oleh mereka. Moore (2009:47) menyatakan: "Student learn more and retain more when the material they are learning is thought in a manner that is comfortable for them. Thus, astudents learn through different channels: that is, they have different learning style". Materi yang membuat mahasiswa senang belajar akan lebih memudahkan mereka untuk menyerap ilmu dalam materi yang ada. Sayangnya hal ini belum mendapat perhatian secara serius oleh para pengajar.

Selama ini belum ada kajian khusus yang mengeksplorasi topik belajar yang diminati oleh para pembelajar BIPA. Berdasar kaji empiris dapat dinyatakan bahwa pembelajaran dalam kelas program transfer kredit ini dipengaruhi oleh topik kajian yang dibahas dalam kelas. Kondisi kelas menunjukkan bahwa tidak semua topik materi menarik bagi mahasiswa. Topik belajar yang menarik akan membuat kelas hidup dan mahasiswa semangat belajar, sedangkan jika topiknya tidak disukai maka kelas akan nampak lesu dan tidak hidup.

Topik belajar menjadi acuan bagi pengajar dan pembelajar dalam proses belajarnya. Dalam berbagai aspek pembelajaran, topik belajar akan mendukung pelaksanaan kelas menjadi baik atau sebaliknya. Persiapan dalam pembelajaran

Topik Pilihan Mahasiswa Tiongkok dalam Pembelajaran BIPA Program Transfer Kredit di UNY 
BIPA perlu dilakukan untuk mendapatkan hasil belajar yang maksimal. Oleh karena itu, masalah dalam penelitian ini meliputi: (1) Topik apa yang paling diminati mahasiswa Tiongkok dalam belajar bahasa Indonesia (secara umum dan per aspek keterampilan berbahasa)? (2) Mengapa mahasiswa Tiongkok memiliki kecenderungan belajar bahasa Indonesia dengan topik tertentu? (3) Bagaimana pengaruh hasil eksplorasi minat topik belajar bahasa Indonesia mahasiswa Tiongkok terhadap pembelajaran BIPA program transfer kredit?

\section{METODE}

Penelitian ini merupakan penelitian kualitatif. Pendekatan ini digunakan dengan dasar bahwa orientasi penelitian ini adalah untuk memahami dan mengeksplorasi lebih jauh tentang topik pilihan mahasiswa Tiongkok dalam pembelajaran BIPA program transfer kredit di UNY. Dalam penelitian ini, peneliti hadir sebagai instrumen kunci.

Lokasi penelitian ini adalah di Universitas Negeri Yogyakarta tahun 2015 dengan subjek penelitian sebanyak 40 mahasiswa Tiongkok yang sedang mengambil program transfer kredit di UNY selama 2 semester. Di UNY terdapat 2 kelas program transfer kredit dari Tiongkok. Satu kelas (20 mahasiswa) dari Guanzhou, GDUFS (Guangdhong Universities for Foreign Studies). Satu kelas lainnya (20 mahasiswa) dari Yunan, Yunan Minzu University. Beberapa data juga diperoleh dari mahasiswa Tiongkok yang telah menempuh program transfer kredit di tahun sebelumnya. Pengumpulan data menggunakan angket, wawancara, dan studi dokumentasi. Data dalam penelitian ini berupa data kualitatif yang berwujud verbal tertulis dan verbal lisan. Verbal tertulis berupa catatan, jawaban, komentar, saran, kritikan, masukan atau paparan informasi apapun yang diperoleh secara tertulis dalam angket yang diberikan.
Data verbal lisan adalah semua paparan informasi yang diperoleh dari subjek penelitian dengan teknik wawancara. Wujud data lainnya adalah semua informasi yang ada dalam hasil belajar yang diperoleh dari penelusuran studi dokumentasi.

Pengolahan data menggunakan pengolahan data kualitatif. Data yang diperoleh diorganisasi, dipilah-pilah, disintesis, dicari aspek yang penting, dan diputuskan apa yang dapat diceritakan kepada orang lain (Bogdan \& Biklen, 2006). Teknik analisis data yang digunakan dalam penelitian ini merupakan teknik yang dimodifikasi dari berbagai sumber. Teknik analisis data penelitian ini mencakup: pendokumentasian data dan dan proses pengumpulan data, pengorganisasian/kategorisasi data ke dalam konsep, pengoneksian data untuk menunjukkan bagaimana satu konsep dapat mempengaruhi yang lain, pembuatan legitimasi dengan mengevaluasi penjelasan alternatif - penyediaan bukti dan pencarian kasus negatif, dan terakhir adalah pelaporan hasil temuan.

Keabsahan data harus terjamin dari sebuah penelitian. Cara pengecekan keabsahan temuan dalam penelitian ini menggunakan trianggulasi data, baik metode pengumpulan data maupun interdiciplinary triangulation. Peneliti juga melakukan pengecekan ulang. Data yang diperoleh dicek ulang, di-crosscheck, antara data dari berbagai sumber yang telah diperoleh. Pengecekan dilakukan berulang sampai mendapatkan data yang benar-benar absah.

\section{HASIL DAN PEMBAHASAN}

Pembelajaran BIPA dalam program transfer kredit di UNY disajikan dalam berbagai mata kuliah yang pada awalnya diprogram berdasar kesepakatan kedua universitas yang bersangkutan. Beberapa mata kuliah berbasis pada kebutuhan dasar BIPA yang mencakup empat keterampilan berbahasa dan pengetahuan kebahasaan, selain beberapa mata kuliah 
lain yang sesuai dengan kebutuhan para mahasiswa Tiongkok tersebut. Mata kuliah yang ada, khususnya pada empat keterampilan berbahasa, tersajikan berdasar pada topik tertentu yang diancang oleh pengajarnya. Dalam pembelajaran BIPA program transfer kredit ini nampak kecenderungan topik-topik yang diminati para mahasiswa dalam tiap aspek belajar. Mereka mempunyai alasan dalam memilih topik tersebut dan hal ini sebaiknya dikelola oleh pengajar BIIPA agar pembelajaran dapat berhasil baik.

\section{Topik Pilihan Mahasiswa Tiongkok dalam Pembelajaran BIPA}

Secara umum pembelajaran bahasa Indonesia bagi mahasiswa Tiongkok ini diberikan dengan dasar tematik. Tema yang terdapat dalam modul yang ada di antaranya adalah budaya, kesehatan, politik, pendidikan, hiburan, wisata, sosial, ekonomi, hukum, kesehatan, teknologi, dan layanan masyarakat. Dalam cakupan tema itu materi keterampilan berbahasa disajikan, seperti membaca, berbicara, menyimak, dan menulis. Namun demikian, pengajar (dosen) memiliki kewenangan dalam mengembangkan materi yang ada.

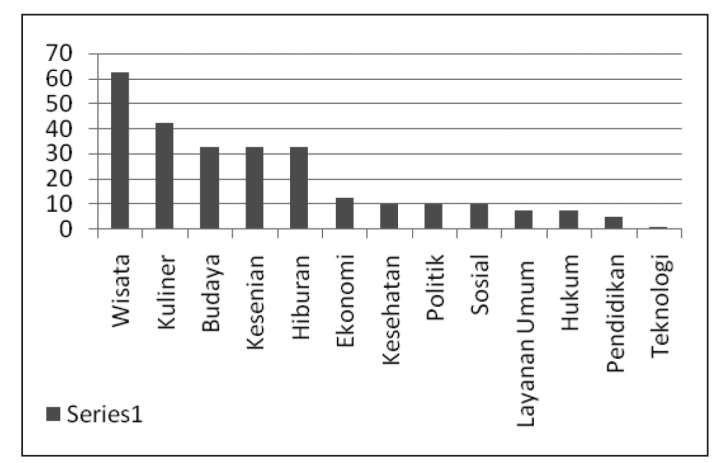

Gambar 1. Bagan Persentase Minat Topik Belajar BI Mahasiswa Tiongkok

Berdasarkan hasil penelitian, secara umum mahasiswa Tiongkok menyukai beberapa topik belajar, seperti wisata $(62,5 \%)$, kuliner $(42,5 \%)$, budaya $(32,5 \%)$, kesenian (32,5\%), hiburan (32,5\%), ekonomi $(12,5 \%)$, kesehatan (10\%), politik $(10 \%)$, sosial $(10 \%)$, layanan umum $(7,5 \%)$, hukum $(7,5 \%)$, pendidikan $(5 \%)$, dan teknologi (1\%). Berikut sajian visual hasil penelitian tersebut.

Hasil angket menunjukkan bahwa sebagian besar mahasiswa Tiongkok menyukai topik wisata saat mempelajari bahasa Indonesia. Bukan berarti topik lain tidak menarik bagi mereka, namun wisata menjadi sebuah pesona tersendiri untuk mengenal Indonesia. Hal ini juga nampak dalam penghitungan jumlah mahasiswa dalam kaitan topik belajar di pembelajaran keterampilan berbahasa.

Wisata menjadi sebuah daya tarik saat mengunjungi suatu tempat atau negara. Hal ini disebabkan adanya promosi yang dapat diakses oleh para mahasiswa. Promosi wisata dapat diperoleh dari berbagai media seperti internet, brosur, majalah, televisi, maupun biro wisata. Di kampus, mahasiswa asing juga bergaul dengan mahasiswa Indonesia. Mahasiswa Indonesia ini merupakan duta wisata yang memiliki peran dalam besarnya minat mahasiswa asing terhadap topik wisata. Susanti (2010:34) mengungkapkan bahwa mahasiswa Indonesia (di luar negeri) dapat menjadi mitra pemerintah dalam memberi pencerahan dan mem-breakdown berbagai daya tarik wisata di masingmasing daerah asal mahasiswa khususnya dan Indonesia secara universal. Hal ini ternyata berlaku juga bagi mahasiswa yang di dalam negeri, mereka menjadi duta wisata daerahnya yang menyebarkan info wisata pada mahasiswa asing yang ada di kampusnya. Rasa ingin tahu dan kesempatan atau mumpung ada di Indonesia digunakan mahasiswa asing untuk wisata. Oleh karena itu, topik menarik dalam belajar bahasa pun adalah wisata. Mereka dapat lebih mengenal dunia wisata Indonesia melalui belajar bahasa Indonesia. 
Topik wisata selalu berada dalam tiga besar topik yang paling diminati oleh para pembelajaran ini. Berikut ini adalah sajian tabulasi penghitungan persentase minat topik belajar dari 40 mahasiswa Tiongkok yang sedang mengambil program kredit transfer di UNY.

Tabel 1. Hasil Penghitungan Minat Topik Belajar Mahasiswa Tiongkok

\begin{tabular}{|c|c|c|c|}
\hline \multirow[t]{2}{*}{ Topik } & \multicolumn{3}{|c|}{$\begin{array}{l}\text { Jumlah Peminat Topik Belajar } \\
\text { (dalam } \%)\end{array}$} \\
\hline & Membaca & Menulis & $\begin{array}{c}\text { Menyimak- } \\
\text { Berbicara }\end{array}$ \\
\hline Kuliner & 52,5 & 25 & 27,5 \\
\hline Wisata & 52,5 & 45 & 42,5 \\
\hline Hiburan & 52,5 & 5 & 50 \\
\hline Budaya & 35 & 20 & 35 \\
\hline Hidup Sosial & 15 & 5 & 7,5 \\
\hline Ekonomi & 12,5 & 2,5 & 2,5 \\
\hline Politik & 7,5 & 0 & 10 \\
\hline Kesehatan & 7,5 & 0 & 10 \\
\hline Hukum & 2,5 & 0 & 0 \\
\hline Layanan Umum & 0 & 2,5 & 0 \\
\hline
\end{tabular}

Dalam Tabel 1, pada keterampilan membaca mayoritas mahasiswa menyukai topik kuliner, wisata, dan hiburan yang masing-masing sebesar 52,5\%. Topik yang diminati dalam kegiatan menulis cenderung pada topik wisata (45\%). Hal ini mencakup berbagai daerah wisata di Indonesia dan keindahan alam Indonesia, termasuk wisata di negara asalnya juga, Tiongkok. Sementara dalam hal keterampilan berbahasa lisan (menyimak dan berbicara), mahasiswa Tiongkok cenderung menyukai topik belajar tentang hiburan (50\%). Topik hiburan mencakup musik, lagu daerah, humor dalam televisi, dan hal lain yang tergolong dunia hiburan. Dari keempat puluh mahasiswa, mereka menyebutkan beberapa topik yang disukai dalam belajar. Namun demikian, mereka juga menyebutkan topik yang paling disukainya. Perhitungan persentase menunjukkan jika mahasiswa Tiongkok suka topik yang sederhana dan tidak terlalu rumit, yaitu kuliner, wisata, dan hiburan. Berikut ini adalah tampilan visual dari penghitungan di atas.

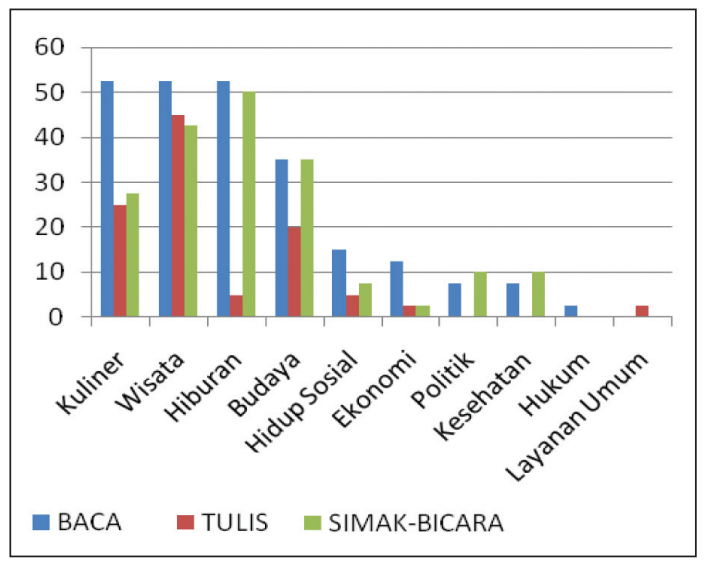

Gambar 2. Bagan Persentase Topik

Pilihan Mahasiswa Tiongkok dalam

Belajar Keterampilan Berbahasa Indonesia

Belajar bahasa Indonesia dalam BIPA merupakan pembelajaran yang integratif. Artinya, ada perpaduan dalam tiap aspek belajar dan keilmuan yang berbagai macam. Pengintegrasian dilakukan interbidang dan antarbidang. Ranah topik pilihan mahasiswa itu sesungguhnya memberi cermin keingintahuannya akan Indonesia, seiring proses belajar bahasa Indonesia. Tiap tahun ada kecenderungan berbeda minat topik belajarnya karena pembelajaran bahasa sangat tergantung pribadi pembelajarnya. Bahkan, dalam satu tahun belajar topik minat pembelajar dapat berubah-ubah juga. Hal ini sangat dipengaruhi oleh banyak hal selama mereka belajar.

\section{Berbagai Alasan Kecenderungan Minat Topik Belajar Mahasiswa Tiongkok Be- lajar Bahasa Indonesia}

Munculnya topik-topik belajar dalam pembelajaran bahasa Indonesia untuk penutur asing adalah upaya untuk memudahkan pembelajaran sekaligus memberi wawasan keindonesiaan. Pembelajaran akan lebih bermakna ketika subjek belajar dilibatkan dalam pembelajaran secara 
aktif. Minat mahasiswa pada topik belajar akan banyak mempengaruhi kondisi belajar dan hasil belajarnya. Pembelajaran yang bermakna akan meninggalkan kesan lebih lama dalam diri pembelajarnya.

Kegiatan wawancara dalam penelitian ini mengungkap berbagai alasan kecenderungan minat topik belajar mahasiswa Tiongkok. Wisata menjadi topik yang paling disukai. Ada banyak yang diungkap mahasiswa mengapa topik ini menarik bagi mereka. Pertama, Indonesia dikenal dengan alamnya yang indah. Mahasiswa Tiongkok sangat tertarik untuk mengeksplorasi alam Indonesia. Namun demikian, tujuan mereka datang ke Indonesia adalah belajar. Oleh karena itu, sebagian besar waktu mereka adalah untuk belajar. Padahal mereka sangat ingin berkeliling Indonesia. Dengan adanya topik wisata mereka dapat menjelajahi dunia wisata Indonesia meskipun berada dalam kelas. Bagi mahasiswa Tiongkok, kunjungan ke Indonesia sebagian besar adalah pengalaman pertama mereka ke luar negeri dan bebas dari orang tua. Sebagian besar mereka adalah anak tunggal dan tidak biasa dibebaskan oleh orang tuanya. Mereka ingin menikmati wisata di Indonesia secara bebas. Namun, keterbatasan waktu menjadikan mereka harus selektif memilih tempat wisata yang memungkinkan untuk mereka kunjungi.

Wisata mereka angkat dalam tulisan juga tidak semata hanya tentang wisata. Perpaduan dengan unsur budaya atau bahkan politik mereka lakukan dalam membuat tulisan terkait dengan tempat wisata. Misalnya dalam tulisan Wang Liting (2014) yang berjudul "Kepercayaan Masyarakat Yogyakarta terhadap Gunung Merapi". Dalam tulisan tersebut Wang Liting mengungkap indahnya wisata gunung Merapi dan sekaligus budaya ritual kepercayaan masyarakat sekitarnya. Tulisan Wang Chujun (2014) memadukan topik wisata dengan politik. Ia menulis pesona wisata di Aceh dan politik oto- nomi daerahnya. Secara pintar mahasiswa Tiongkok memadukan topik yang ia minati dengan hal lain yang membuat tulisannya menjadi lebih berisi.

Kedua, topik yang mereka minati adalah kuliner. Perbedaan kuliner Indonesia dan Tiongkok menjadi alasan utama mereka menyukai topik ini. Mereka suka mencoba berbagai makanan dan minuman Indonesia. Pada usianya, mahasiswa Tiongkok masih suka mencoba hal baru. Mereka merasa ada nilai khas dalam kuliner Indonesia. Kehidupan keseharian mereka di Indonesia dihadapkan dengan berbagai makanan dan minuman Indonesia sehingga bagi mereka dunia kuliner adalah pengalaman faktual. Pengalaman faktual ini sangat bagus untuk pembelajaran bahasa asing, terutama dalam perwujudan input dan pencapaian output (Krashen, 1997:229). Pengalaman faktual dalam hidup mahasiswa di Indonesia ini akan memberi pemahaman baru tentang budaya Indonesia yang secara integratif menjadi bagian dalam pembelajaran BIPA.

Berikutnya, topik hiburan juga menjadi salah satu topik yang sangat mereka minati. Alasan yang kuat dalam hal ini adalah keberadaan mereka selama satu tahun di Indonesia yang ingin mereka jadikan sebagai bagian hidup yang santai. Kehidupan di Tiongkok sangat ketat aturan dan keras. Budaya belajar mereka sangat tinggi tuntutannya. Mereka hanya mempunyai sedikit waktu bersenangsenang di Tiongkok. Setelah selesai kuliah mereka harus bekerja dan waktu untuk hiburan sangat terbatas. Materi hiburan menurut mereka santai dan menyenangkan. Mereka merasa tidak terlalu harus banyak berpikir. Mereka belajar tapi sambil bersenang-senang mengetahui berbagai ragam hiburan di Indonesia dan wilayah lainnya. Apalagi adanya larangan "bebas internet" di Tiongkok membuat mahasiswa sangat terbatas akses hiburan dari dunia maya. 
Topik lain yang mereka minati adalah budaya. Persamaan dan perbedaan budaya antara Indonesia-Tiongkok menjadi salah satu alasan mereka menyukai topik ini. Dalam beberapa topik lain, mahasiswa Tiongkok sering melakukan komparasi antara kondisi di negaranya dan di Indonesia. Mereka juga tertarik dengan budaya masyarakat keturunan Tiongkok yang ada di Indonesia. Misalnya, Zeng Yun (2014) yang tertarik dengan budaya Hokkian dalam masyarakat Indonesia, dan Wu Xuan (2015) yang membahas bahasa dan budaya Tiongkok dalam kehidupan masyarakat keturunan Tiongkok di Indonesia. Beberapa mahasiswa Tiongkok juga tertarik mencari runutan sejarah etnis Tionghoa di Indonesia. Masalah etnis dan keberadaan daerah Pecinan juga menarik bagi para mahasiswa Tiongkok. Hal ini berangkat dari sejarah munculnya wijkenstesel, yaitu sebuah peraturan yang melarang orang Tionghoa untuk tinggal di tengah kota dan membangun wilayah Pecinan sebagai daerah hunian khusus orang Tionghoa (Jusuf, 2001:49).

Topik ekonomi tidak menjadi topik yang banyak disukai tetapi tetap ada mahasiswa yang mempunyai minat dalam bidang itu. Perekonomian Indonesia dan Tiongkok yang berkembang menjadi alasan keingintahuan belajar tentang hal tersebut. Demikian juga topik lain, meskipun tidak banyak yang meminati tetapi ada keinginan mahasiswa untuk belajar tentang politik, kesehatan, hukum, kehidupan sosial, layanan masyarakat, dan lainnya.

Setiap tahun ada mahasiswa berganti. Topik belajar yang diminati pun kadang juga tidak selalu sama. Berdasar angket tahun ini mahasiswa sebagian besar berminat ke topik wisata dan kuliner. Pada tahun lalu, mahasiswa lebih menyukai kehidupan sosial di Indonesia. Data dari dokumentasi menunjukkan hal tersebut. Beberapa tulisan dan bahasan menarik yang diperoleh dari dokumen tulisan dan logbook kelas menunjukkan bahwa tahun lalu mahasiswa Tiongkok cenderung berminat saat membahas anak jalanan, pengamen, poligami di Indonesia, kehidupan waria, budaya gotong royong, dan budaya mudik.

Pengaruh Eskplorasi Minat Topik Belajar Mahasiswa Tiongkok dalam Pembelajaran BIPA Program Transfer Kredit

Apapun materi yang disajikan, peran seorang pengajar tetap sangat penting untuk membuat kelas berhasil. Eksplorasi terhadap minat topik belajar para mahasiswa Tiongkok ini akan memberikan gambaran bagi pengajarnya untuk mengelola kelas menjadi lebih menarik dan menyenangkan. Mengajar pada prinsipnya adalah mentransfer pengetahuan. Mahasiswa adalah subjek belajar yang harus aktif dalam belajar.

Salah satu hal penting dalam pembelajaran BIPA adalah mengetahui kebutuhan pembelajarnya dan peka terhadap kondisi pembelajar. Eksplorasi minat topik belajar ini akan memberi gambaran pembelajar. Setiap tahun pasti tidak sama minatnya karena pembelajarnya tidak sama. Akan tetapi, kecenderungan minat dan alasannya akan menjadi dasar bagi pengajar untuk menyiapkan kelas secara lebih baik dan matang. Persiapan kelas dapat berupa materi, media, dan pendukung pembelajaran lainnya. Hal ini menguatkan penelitian ke-BIPA-an terdahulu yang dilakukan Suharsono (2015:51-73) yang menyebutkan bahwa hasil penelitiannya berimplikasi pada muara dasar pengembangan materi ajar BIPA dan pengajarannya yang harus memperhitungkan berbagai hal, termasuk kesulitan siswa. Penelitian kali ini mengemukakan bahwa minat topik belajar dapat mempengaruhi pembelajaran BIPA dan dapat dijadikan dasar pengembangan materi ajar BIPA. Pengajar kelas BIPA juga harus peka terhadap pembiasaan mahasiswanya. 
Pembelajaran bahasa asing, termasuk BIPA, selalu meleburkan bahasa dengan konteks nyata situasi yang ada di sekitarnya. Tidak cukup mengajarkan struktur, pengetahuan bahasa, kosakata, ekspresi bahasa, tetapi perlu adanya situasi dan kondisi nyata. Kehidupan sekitar yang dialami dan diminati para mahasiswa akan mempengaruhi pembelajaran BIPA menjadi lebih bermakna. Jiang (2000) mengatakan bahwa antara bahasa dan budaya selalu saling mempengaruhi, keduanya tidak ada tanpa keberadaan lainnya. Budaya dalam hal ini adalah lingkungan sekitar pembelajar. Dengan memahami keinginan dan disinergikan dengan kebutuhan pembelajar maka pembelajaran akan lebih berhasil. Dari 40 mahasiswa Tiongkok yang mengisi angket dalam penelitian ini 97,5\% menyatakan bahwa belajar bahasa Indonesia dengan topik yang disukai akan membuat pembelajaran lebih menyenangkan dan mudah. Modal itu sudah sangat kuat bagi pengajar untuk membuat kelas BIPA menjadi menyenangkan dan bermakna.

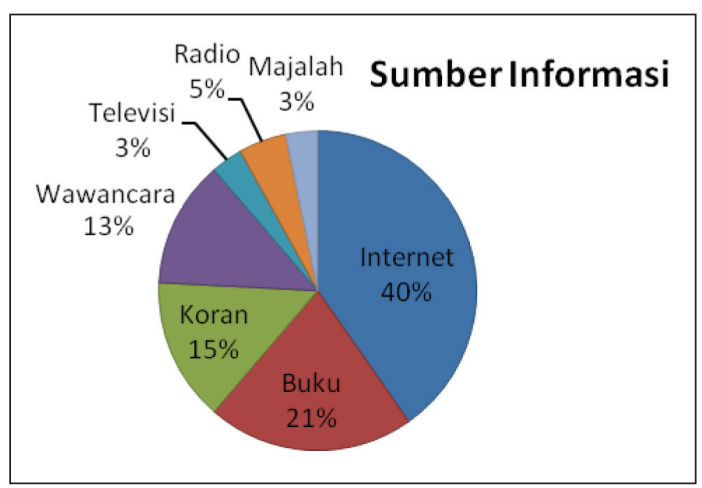

Gambar 3. Diagram Sumber Informasi Referensi Topik Mahasiswa Tiongkok

Pengajar juga harus dapat mengimbangi dan memperluas wawasannya sesuai topik pembelajaran. Perkembangan informasi yang pesat menuntut pengajar BIPA harus selalu dapat mengikuti perkembangan informasi yang ada. Apalagi pembelajar Tiongkok ini sebagian besar mencari data informasi melalui media internet. Laju informasi dalam dunia internet sangat cepat dan hal ini harus dapat diikuti pengajarnya. Berikut sumber informasi yang digunakan para pembelajar Tiongkok terkait berbagai topik yang diminatinya.

Pengajar program transfer kredit harus dapat mengimbangi kebiasaan mahasiswa dan memberikan masukan referensi sesuai kebutuhan mereka. Keterbatasan kemampuan bahasa Indonesia dan fasilitas media di tempat tinggal para mahasiswa menjadi faktor penentu juga sehingga hasil kajian menunjukkan bahwa mereka mengandalkan internet sebagai sumber utama. Kebebasan mengakses dari internet di Indonesia juga menjadi faktor lain yang mempengaruhi hal tersebut. Eksplorasi minat topik ini dapat menjadi ancangan pengajar guna menyiapkan materi dan memadupadankan dengan topik lain yang harus diberikan pada mahasiswa. Pengajar kiranya dapat memberi dan menyiapkan referensi lain bagi para mahasiswa secara variatif. Topik yang diminati mahasiswa dapat menjadi acuan pengembangan materi. Haiguang (2015:348) menyatakan bahwa Bahasa Indonesia yang kaya afiks, sedangkan bahasa Tionghoa justru sebaliknya. Pengajar dapat membelajarkan berbagai afiks dalam Bahasa Indonesia melalui berbagai cara dengan topik-topik yang menarik bagi mahasiswa. Kesiapan pengajar maupun ketersediaan sumber belajar yang memadai akan membuat pembelajaran BIPA dapat mencapai hasil yang maksimal.

\section{SIMPULAN}

Berdasar uraian di atas dapat disimpulkan beberapa hal sebagai berikut. Pertama, secara umum mahasiswa Tiongkok dalam program transfer kredit di UNY mempunyai kecenderungan minat topik belajar dalam kelas BIPA. Topik yang mereka sukai secara berurutan

Topik Pilihan Mahasiswa Tiongkok dalam Pembelajaran BIPA Program Transfer Kredit di UNY 
sesuai banyaknya persentase pilihan adalah wisata, kuliner, budaya, kesenian, hiburan, ekonomi, kesehatan, politik, sosial, layanan umum, hukum, pendidikan, dan teknologi. Dalam pembelajaran membaca, sebagian besar dari mereka menyukai topik kuliner, wisata, dan hiburan. Dalam kegiatan menulis, mereka paling menyukai topik wisata. Dalam kegiatan menyimak-berbicara, mereka paling menyukai topik hiburan.

Kedua, mahasiswa Tiongkok memiliki minat pada bidang wisata, kuliner, dan hiburan atau lainnya karena berbagai alasan, seperti ketertarikan akan alam Indonesia yang indah dan keinginan berwisata di wilayah Indonesia, kuliner Indonesia yang variatif, dunia hiburan yang dapat membuat santai, budaya Indonesia yang beragam, dan pembandingan dengan kondisi di negara mereka. Kehidupan faktual keseharian mereka tinggal di Indonesia membuat mereka lebih ingin mengenal dan memahami Indonesia dari sisi tersebut. Ketiga, eksplorasi minat topik belajar yang dimiliki mahasiswa Tiongkok selama belajar BIPA ini merupakan kajian yang dapat bermanfaat untuk menyiapkan kelas BIPA lebih bermakna. Pengajar dapat memahami keinginan dan memadukan dengan kebutuhan mahasiswa dalam belajar BIPA. Pengajar juga dapat senantiasa mengikuti informasi yang mahasiswa peroleh dari berbagai sumber dan menyediakan referensi lain secara lebih memadai bagi mahasiswanya. Pengembangan bahan ajar dapat dilakukan dengan mempertimbangkan topik yang diminati oleh mahasiswa sehingga pembelajaran dapat lebih menarik.

\section{UCAPAN TERIMA KASIH}

Artikel ini disarikan dari penelitian mandiri yang dilakukan dalam rangka salah satu penugasan kuliah di jenjang S3 yang dilakukan peneliti. Ucapan terima kasih disampaikan kepada Prof. Dr. Djoko
Saryono, M.Pd. dan Prof. Dr. Suyono, M.Pd. selaku Pembina mata kuliah publikasi hasil penelitian yang telah berkenan memberikan saran dan masukan dalam proses penelitian dan penulisan artikel. Terima kasih pula disampaikan pada para tutor dan para mahasiswa GDUFS atas partisipasinya dalam membantu penelitian ini.

\section{DAFTAR PUSTAKA}

Bogdan, Robert C. and Biklen, Sari Knopp. 2007. Qualitative Research for Education - an Introduction to Theory and Methods. Fifth Edition. New York: Pearson.

Brown, H.D. 2007. Principles of Language Learning and Teaching( $5^{\text {th }}$ ed.). New York: Pearson Education.

Haiguang, Yuan. 2015. "Studi Kontrastif Kalimat Pasif Bahasa Indonesia dan Tionghoa". Jurnal Litera, Volume 14, Nomor 2, Oktober.

Jiang, W. 2000. "The Relationship Between Culture and Language". ELT Journal, 54 (4), 328 - 334. Retrieved on the August, $12^{\text {th }}$ 2014. http://203.72.145.166/ elt/files/54-4-3.pdf.

Jusuf, Ester Indahyani. 2002. "Jalan Panjang Menuju Rasionalisme" dalam Jurnal Dinamika Hak Asasi Manusia, Vol. 2, No. 2, Januari - Juni.

Krashen, S.D. \& Terrell, T.D. 1997. The Natural Approach: Language Acquisition in the Classroom. Oxford: Pergamon Press.

Moore. 2009. Effective Instructional Strategies from Theory to Practice. $2^{\text {nd }}$ ed. London: Sage.

Suharsono. 2015. "Pemerolehan Klausa Relatif pada Pemelajar Bahasa Indonesia bagi Penutur Asing (BIPA): Kajian Bahasa-Antara". Jurnal Litera, Volume 14, Nomor 1, April.

Susanti, Sri. 2010. "Mahasiswa sebagai Duta Promosi Pariwisata Indonesia di Luar Negeri". Jurnal Analisis Pariwisata, Vol. 10, No. 1, Tahun 2010. 